OPEN ACCESS

Edited by:

Fabricio Beggiato Baccaro,

Federal University of Amazonas, Brazil

Reviewed by:

Fernando Dagosta

Federal University of Grande

Dourados, Brazil

Luciano F. A. Montag,

Federal University of Pará, Brazi

*Correspondence: Elio de Almeida Borghezan

borghezan.ea@gmail.com

Specialty section:

This article was submitted to Biogeography and Macroecology,

a section of the journal

Frontiers in Ecology and Evolution

Received: 31 July 2020 Accepted: 03 December 2020

Published: 07 January 2021

Citation:

Borghezan EA, Pires THS Ikeda T, Zuanon J and Kohshima S (2021) A Review on Fish Sensory Systems and Amazon Water Types With Implications to Biodiversity.

Front. Ecol. Evol. 8:589760 doi: $10.3389 /$ fevo.2020.589760

\section{A Review on Fish Sensory Systems and Amazon Water Types With Implications to Biodiversity}

\author{
Elio de Almeida Borghezan ${ }^{1,2 *}$, Tiago Henrique da Silva Pires ${ }^{2}$, Takehide Ikeda1, \\ Jansen Zuanon ${ }^{2}$ and Shiro Kohshima ${ }^{1}$ \\ ${ }^{1}$ Wildlife Research Center of Kyoto University, Kyoto, Japan, ${ }^{2}$ Laboratório de Ecologia Comportamental e Evolução, \\ Coordenação de Biodiversidade, Instituto Nacional de Pesquisas da Amazônia, Manaus, Brazil
}

The Amazon has the highest richness of freshwater organisms in the world, which has led to a multitude of hypotheses on the mechanisms that generated this biodiversity. However, most of these hypotheses focus on the spatial distance of populations, a framework that fails to provide an explicit mechanism of speciation. Ecological conditions in Amazon freshwaters can be strikingly distinct, as it has been recognized since Alfred Russel Wallace's categorization into black, white, and blue (= clear) waters. Water types reflect differences in turbidity, dissolved organic matter, electrical conductivity, $\mathrm{pH}$, amount of nutrients and lighting environment, characteristics that directly affect the sensory abilities of aquatic organisms. Since natural selection drives evolution of sensory systems to function optimally according to environmental conditions, the sensory systems of Amazon freshwater organisms are expected to vary according to their environment. When differences in sensory systems affect chances of interbreeding between populations, local adaptations may result in speciation. Here, we briefly present the limnologic characteristics of Amazonian water types and how they are expected to influence photo-, chemical-, mechano-, and electro-reception of aquatic organisms, focusing on fish. We put forward that the effect of different water types on the adaptation of sensory systems is an important mechanism that contributed to the evolution of fish diversity. We point toward underexplored research perspectives on how divergent selection may act on sensory systems and thus contribute to the origin and maintenance of the biodiversity of Amazon aquatic environments.

Keywords: Amazon fish evolution, divergent pressure, divergent selection, ecological speciation, local adaptation, sensory drive, biodiversity

\section{INTRODUCTION}

Fish comprise the most diverse group of vertebrates, with nearly 35.635 extant species (as listed in Catalog of Fishes in October 2020, Fricke et al., 2020). Of that total, almost 18.000 species are found only in freshwater ecosystems (Fricke et al., 2020). The Neotropical region contributes the largest part of this astonishing diversity, harboring over 6,000 species (Albert and Reis, 2011; 
Reis, 2013). Most Neotropical freshwater fish diversity occurs in the Amazon basin, where circa 3,000 valid species occur (Dagosta and de Pinna, 2019). Many hypotheses considering different factors as evolutionary drivers of the Amazon fish biodiversity have been developed (Dagosta and de Pinna, 2018). Alfred Russell Wallace (1853) was the first to hint possible ecological reasons for Amazonian fish diversity (Pires et al., 2018). Wallace (1853) highlighted the differences of Amazon fish composition varied according to a classification based on water color (later known as water types) and suggested that those environmental differences could represent an important component of fish diversification. Later, Roberts (1972) proposed that colorful fish species are more abundant in clear and black water types than in white water type, suggesting an effect of water color in shaping the evolution of the Amazon fish coloration. Segregation of ecological niches driven by divergence in ecomorphological traits (e.g., adaptation to divergent feeding niches) has also been suggested as an important component in shaping Amazonian fish diversity (Kullander, 1986). Despite such early efforts in documenting ecological features that could be related to biodiversity, focus later shifted to contrasting sympatric and allopatric speciation (Géry, 1984; Albert and Reis, 2011; Albert et al., 2011; Bernardi, 2013), a framework that fails to specify mechanisms of organismal divergence (Nosil, 2012). This occurred in the light of important advancements in the understanding of landscape evolution of the Amazon basin, which includes how the uplift of the Andean cordilleras altered landscape features. Time is ripe for blending older and newer approaches, and pave the way for the development of newer hypotheses that can be tested and contrasted. Here, we focus on the diversity of aquatic environments as a stepping stone to provide a further appreciation into how divergent selection could contribute to shaping Amazon freshwater biodiversity.

Compared to air, water is a much better conductor of chemical compounds, electric fields and mechanical waves; consequently, most research on the importance of these environmental characteristics in driving diversity has been conducted on aquatic animals (Cummings and Endler, 2018). Despite the contribution of research on aquatic organisms to our understanding of the linkage between environmental conditions, sensory systems and speciation, such studies are nearly absent for Amazon freshwater organisms. For instance, although the sensory drive hypothesis has long established a link between natural selection acting on a tuning between sensorial systems and characteristics of the environment (Endler, 1992; Boughman, 2002), a search for the keywords "Amazon," "fish," and "sensory drive" on Google Scholar returned only 138 studies (searched on 1st May 2020). Only one of these studies actually investigated the sensory drive hypothesis among Amazonian fish species (Pires et al., 2019), and none explicitly investigated any aspect of divergence in their sensory systems. By contrast, the importance of sensory drive in promoting diversification has been suggested for several other taxa in other aquatic environments, especially for African rift lakes organisms.

Individuals use sensory systems to perceive the world surrounding them and respond accordingly. Sensory systems can be divided into four modalities: (I) mechanoreception, (II) electroreception, (III) chemoreception, and (IV) photoreception (Atema et al., 1988). Although most organisms use multimodal information to make decisions, the relative contribution of each modality to how animals perceive their environment differs among taxa. For instance, many electric fish rely more heavily on disturbances in the electric field than on vision or other sensory modalities. In this sense, many environmental components in the Amazon basin can represent sources of divergent selection and potentially drive sensory adaptations. Amazon aquatic habitats and microhabitats vary highly in several important ecological aspects such as the composition of the substrate, openness of the riparian forest canopy, composition of the surrounding forest and presence of floating meadows in river-floodplain systems. We acknowledge the importance of all of these aspects in driving adaptations of fish sensory systems; however, here we focus on how limnologic differences between Amazon water types may have resulted in local adaptation and contributed through divergent selection processes to Amazon fish diversity.

\section{Limnologic Characteristics of Amazon Aquatic Systems}

Amazon water types were originally described according to their apparent coloration as seen from above the water into black, blue (= clear; Sioli, 1984), and white (Wallace, 1853; Figure 1). These differences in coloration stem from variable amounts of suspended particles, the degree of organic material leaching from the surrounding forests, and from the historical geomorphological characteristics of the drainage system (Leenheer, 1980). Soil types in the Amazon are highly diverse, especially due to the different degrees of weathering observed between relatively recent geological formations (such as the Andean cordilleras) and older cratonic regions (such as the Guiana and Brazilian shields) (Quesada et al., 2011).

Table 1 summarizes the main physical and chemical characteristics of white, black, and clear Amazon waters types. Most whitewater rivers have their headwaters on the Andean cordilleras and carry a high concentration of suspended sediments (Goulding et al., 2003) and dissolved salts (Furch, 1984). The Andean sediments increase the concentration of nutrients such as sodium, potassium, magnesium and calcium in the water (Furch, 1984; Table 1), resulting in high biological productivity and a muddy appearance. The high ionic concentration also increases electrical conductivity to a typical range of 68.8 and $93.3 \mu \mathrm{S} / \mathrm{cm}$ (Küchler et al., 2000). The high turbidity constrains vertical light transmission (Muntz, 1978), with a typical local reach of a maximum of $0.50 \mathrm{~m}$ deep (Sioli, 1984; Table 1). The surrounding soil types, mostly latosols and oxisols, favor a more complete decomposition and absorption of organic matter from the surrounding forests (Leenheer, 1980), resulting in lower concentration of dissolved organic carbon (DOC). Because of the low DOC concentration, the $\mathrm{pH}$ of whitewater rivers is close to neutral or slightly alkaline, ranging from 6.2 to 7.2 (Sioli, 1984; Küchler et al., 2000). On the other hand, black and clear water rivers have their headwaters on the old (cratonic) Brazilian and Guiana 


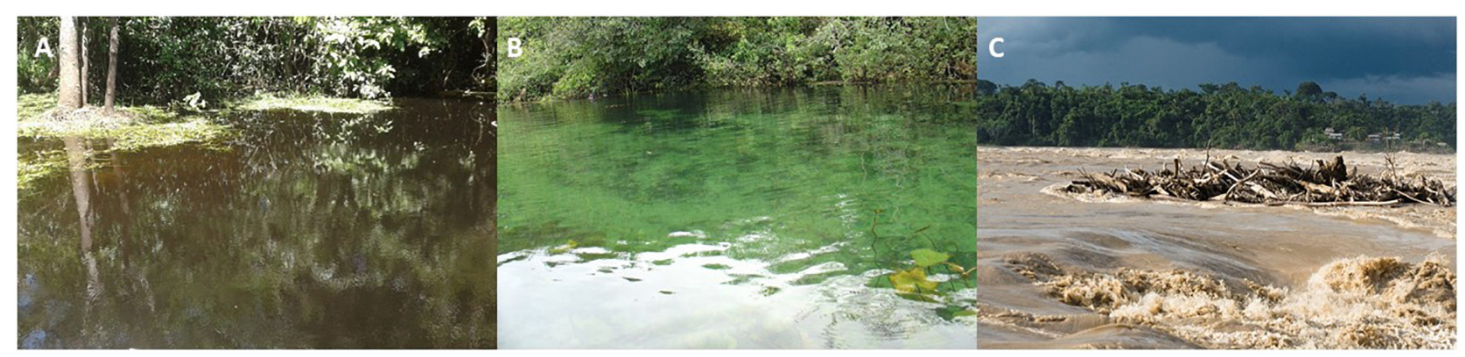

FIGURE 1 | Amazon water types. (A) Black, (B) clear, and (C) white water types. Photo credits: A-Elio Borghezan; B-Jansen Zuanon; C-Tiago Pires.

shields (Goulding et al., 2003). Because of their ancient origin and the long process of lixiviation, these terrains lack fine sediments as well as several minerals (Furch, 1984), resulting in a higher water transparency. Therefore, black waters have lower concentrations of nutrients compared to white waters (Furch, 1984; Table 1). Although more transparent than white waters, black and clear waters are remarkably different in DOC composition. Clear waters have their origin in latosolic soils, which absorb soluble DOC (i.e., humic and fulvic acids), resulting in high transparency ranging from 1.10 to $4.30 \mathrm{~m}$ (Leenheer, 1980; Sioli, 1984). On the other hand, black waters have lower transparency values ranging from 1.3 to $2.9 \mathrm{~m}$ (Sioli, 1984). Black waters are stained by fulvic and humic acids and tannins leached from decomposing vegetation (Leenheer, 1980; Sioli, 1984), biasing light transmission toward long wavelengths (Mendonça et al., 2005; Costa et al., 2013). High concentrations of DOC make black waters remarkably acidic, with $\mathrm{pH}$ ranging from 3.80 to 4.90 , whereas the near absence of DOC in clear waters results in circum-neutral $\mathrm{pH}$ ranging from 4.50 to 7.80 (Sioli, 1984). Black and clear waters also have low electrical conductivity, ranging from 8.80 to $28.60 \mu \mathrm{S} / \mathrm{cm}$ (Küchler et al., 2000; Ríos-Villamizar et al., 2013).

The aforementioned differences in Amazon water characteristics set the stage for natural selection to drive local adaptations in the sensory systems of aquatic organisms. This could have important bearing in Amazonian fish biodiversity, as adaptations to divergent pressures imposed by different

TABLE 1 | Limnologic characteristics of Amazonian white, black and clear water types.

\begin{tabular}{lccc}
\hline & White & Black & Clear \\
\hline $\mathrm{pH}$ & $6.20-7.20$ & $3.80-4.90$ & $4.39-7.80$ \\
Electrical conductivity $(\mu \mathrm{S} / \mathrm{cm})$ & $68.80-93.30$ & $8.80-28.60$ & $14.33-59.90$ \\
Transparency $(\mathrm{m})$ & $0.10-0.50$ & $1.30-2.90$ & $1.10-4.30$ \\
Sodium $(\mathrm{mg} / \mathrm{l})$ & $1.60-2.50$ & $0.33-0.38$ & $1.50-3.88$ \\
Potassium $(\mathrm{mg} / \mathrm{l})$ & $0.90-1.40$ & $0.31-0.32$ & $0.43-2.39$ \\
Calcium $(\mathrm{mg} / \mathrm{l})$ & $4.30-8.60$ & $0.18-0.21$ & $<0.02-2.85$ \\
Magnesium $(\mathrm{mg} / \mathrm{l})$ & $0.70-1.40$ & $0.09-0.11$ & $0.06-0.71$ \\
Chloride $(\mathrm{mg} / \mathrm{l})$ & $2.00-3.10$ & $1.70-1.80$ & $0.53-2.50$
\end{tabular}

Values presented here were combined from data presented by Sioli (1984); Furch (1984), Küchler et al. (2000), and Ríos-Villamizar et al. (2013). habitat conditions can drive populations apart and contribute to the speciation process (Servedio and Boughman, 2017). In the following text, we highlight the role of local adaptations to population divergence by the main sensory modalities (visual, chemical, mechanical, and electrical) through the sensory drive hypothesis (Boughman, 2002; Servedio and Boughman, 2017) in the context of Amazon water types.

\section{Vision}

Light is conceptualized as packets of energy (photons) with varying wavelengths that can be perceived by organisms (Cronin et al., 2014). Ranges of wavelengths represent discrete colors and can elicit different responses from organisms with light-sensitive organs, most notably the eyes. In the eyes, light excites rhodopsin, a photosensitive molecule present in the retina. Rhodopsin is composed of a protein called opsin, and a non-protein part derived from vitamin A (Nelson and Cox, 2014). Rhodopsin can be found in both cone and rod-type retinal cells. There are four spectrally distinct classes of opsins found in cone cell types across all vertebrate groups: long-to-middle wavelength class (LWS), sensitive to orange and red wavelengths (from 490 to $570 \mathrm{~nm}$ ); middle wavelength class ( $\mathrm{RH} 2$ ), sensitive primarily to green (from 480 to $535 \mathrm{~nm}$ ); short wavelength class two (SWS2), sensitive to blue-violet (about 410 to $490 \mathrm{~nm}$ ); , and short wavelength class one (SWS1), sensitive to violet and ultraviolet $(355-440 \mathrm{~nm}$ ) (Bowmaker and Hunt, 2006). In addition to the four cone opsin types, there is a rod class of pigment (usually denoted $\mathrm{Rh}$ ) that is used in dim-light vision perception (Bowmaker and Hunt, 2006).

Genetic analyses have shown that opsin structures differ in individuals living under different lighting conditions (Terai et al., 2006; Seehausen et al., 2008; Van Nynatten et al., 2015). Such differences in opsin structure represent adaptations of the protein to best absorb prevalent wavelengths in the environment (Partridge et al., 1988; Bowmaker and Hunt, 2006). Differences in wavelength transmission among aquatic environments are affected by the presence of particles and dissolved substances in the water column (Endler, 1991). Water molecules absorb long wavelength colors such as red and yellow, while short wavelengths such as violet and ultraviolet are filtered out as depth increases, as observed in the deep African rift lakes (Seehausen et al., 2008). Light can also be scattered by solid particles (Muntz, 1978), reducing the amount of environmental light. Additionally, compounds (usually DOC) present in the water can 
bias the prevalent color in some environments (Endler, 1991; Mendonça et al., 2005). Such bias in wavelength transmission can affect the evolution, form and structure of light-sensitive organs, resulting in differences in light perception between organisms.

Populations can diverge in visual acuity, i.e., the level of details that individuals can discriminate. This ability is primarily influenced by the number of photoreceptors in the retina (cone and rod cells), which is related to eye size and cell density (Collin and Pettigrew, 1988a,b, 1989). A trade-off exists between acuity and sensitivity, as cones allow for greater visual acuity than rods, but rods require less environmental light to function properly. Thus, adaptation to living under low light intensity typically results in lower visual acuity such as seen among deepsea fishes and nocturnal animals (Warrant, 2004). Visual acuity also varies among individuals that occupy different ecological niches and thus have to undertake different visual tasks (Parker et al., 2017). Predators usually have higher visual acuity than herbivores/omnivores (Parker et al., 2017) because of the need to target mobile and sometimes elusive prey.

Amazon water types are spectrally diverse and vary in their optical characteristics (Costa et al., 2013). The high amount of suspended solids in white waters result in high turbidity, which strongly constrains light transmission (Muntz, 1978) and can hamper visual communication. Therefore, it would be expected that individuals living in such conditions would have larger eyes or higher sensitivity to compensate for the low availability of light. By the same token, fishes inhabiting white water systems would be expected to have a higher number of rod cells compared to fish inhabiting clear and black water types. However, when light is mostly absent, the visual system of organisms adapting to such environments can reduce, which can even result in the loss of functional eyes (Soares and Niemiller, 2013). Therefore, either an increased eye size and higher density of rods, or a reduction of the visual system could be expected to occur in white waters depending on fish life-history traits (which also depend on evolutionary history). In any case, low visual acuity and poor vision due to a higher proportion of rod cells are expected to prevail in white water organisms. The lower visual acuity in white water organisms may be compensated by information acquired from other senses, such as chemical and mechanical. On the other hand, black and clear waters are more transparent than white waters (Muntz, 1978), increasing the importance of vision and allowing the development of adaptions of the visual system in relation to other sensory modalities. This is aligned with the aforementioned early observation of Roberts (1972), who proposed that most colorful Amazon fish species are found in black and clear water. However, clear and black water environments differ strongly in wavelength transmission (Muntz, 1978) so that further nuances in the evolution of fish coloration could be expected. Due to the absence of DOC and suspended particles, clear waters have no color bias and are thus better at transmitting blue light (Fuller, 2002) than black waters that are biased toward yellow and red (Muntz, 1978).

The photo sensitive protein, opsin, is composed of about 350 amino acids, and divergences at amino acid positions 164, 181, 261, and 269 for LWS; 86 and 90 for SWS1, and; 118 and 269 for SWS2 have been shown to drive divergence in peak light sensitivity in terrestrial mammals (Bowmaker and Hunt, 2006), which may also be important for fishes and other aquatic organisms. Additionally, changes in other amino acid positions can also result in divergent spectral tuning, as observed among cichlid fishes (Carleton et al., 2005; Seehausen et al., 2008). A similar divergence imposed by natural selection on Amazonian fishes would change the protein structure and light absorbance peak to best absorb the most prevalent wavelengths in black and clear water systems (Bowmaker and Hunt, 2006). The highest difference in color peak sensitivity is expected to occur in the SWS1, SWS2, and LWS opsin genes, which are responsible for $\mathrm{UV}$, violet, blue, and red color sensitivity.

The effect of water type on color perception among species, populations or demes can also affect the evolution of body coloration, physiological/neutrally controlled color changes, and sexual ornamentation, especially among sexually dimorphic, and dichromatic species (e.g., Pires et al., 2019; Pinto et al., 2020; Figure 2). Additionally, because color plays an important role in mating behavior, especially among sexually dimorphic species, differences in color peak sensitivity and sexual traits may mediate reproductive isolation among populations exposed to different water types, resulting in speciation and increasing biodiversity. Although interesting and promising, these hypotheses have been poorly explored with regard to the origin and diversification of the fish fauna in the Amazon basin.

In a recent study, Fabrin et al. (2017) compared LWS genes of 10 Neotropical and 19 African cichlids species. The authors suggested that LWS gene diversity in the Neotropics may surpass those found in the cichlids of African rift lakes. However, analyses considering synonymous and nonsynonymous nucleotide modifications that are needed to assert whether such higher nucleotide diversity implies increased diversity in visual perception are still pending. Although an interesting subject, the results of Fabrin et al. (2017) do not allow comparisons among Amazon water types, as only one sample site in the Amazon was included in the study. Another investigation involving Amazon cichlids performed by EscobarCamacho et al. (2017) evaluated a set of opsin genes, including SWS1, SWS2, RH2, and LWS, among three Amazonian cichlid species and concluded that opsin gene expression profiles were similar across species. Although sampling sites in that study did include black and seasonally mixed (black and white, due proximity of the meeting of the Amazon, and Negro Rivers) water types, the authors did not conduct an explicit comparison of genetic divergence between water types. Another investigation of molecular evolution of light-sensitive protein was performed by Van Nynatten et al. (2015), which showed that the South America (including Amazon) freshwater environments have shaped the evolution of the rhodopsin and its spectral sensitivity among lineages of marine-originated anchovies (Clupeiformes: Engraulidae). However, that study does not consider any of the differences observed among Amazon water types.

Combining microspectrophotometry of fish retina and genetic analysis targeting opsin genes and structure is a promising approach for understanding how light perception varies among species and populations occupying different water types (as reported for other environments by Carleton et al., 2005; 


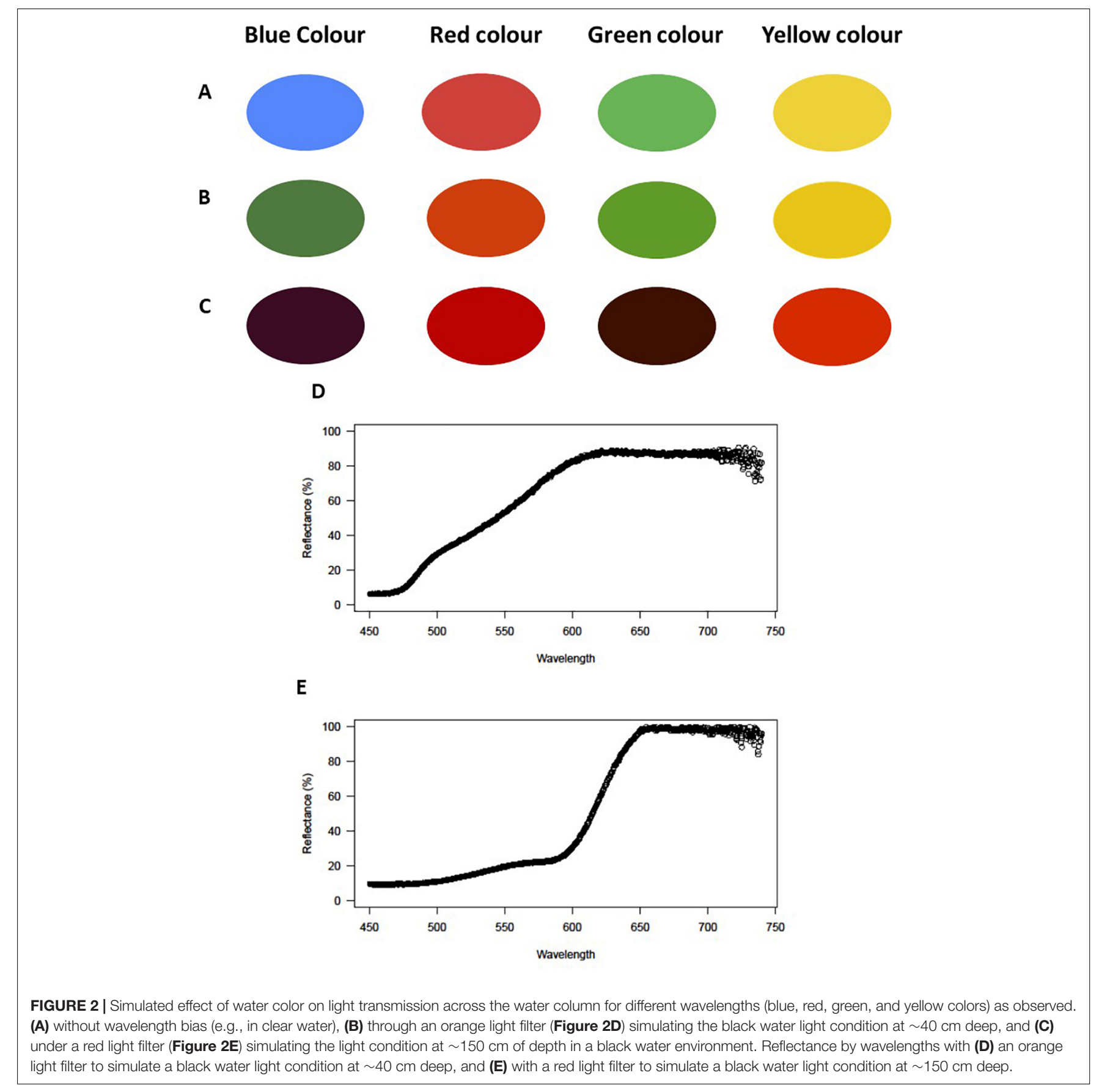

Seehausen et al., 2008). Behavioral experiments, such as mate choice and male-male contests under different light conditions could also contribute to our understanding of how environmental light affects interactions among individuals when exposed to different water types and behavioral contexts (Dijkstra et al., 2005; Seehausen et al., 2008).

Retinal analysis focused on estimating photoreceptor and ganglion cell densities could help with understanding differences in visual acuity (Nakamura, 1968; Collin and Pettigrew, 1989; Parker et al., 2017). Additionally, behavioral experiments could elucidate how differences in retinal topography affects an individual's acuity during behavioral tasks. Because sexually dichromatic species are particularly dependent on visual communication during mating, studies focusing on the interplay of lighting environment and color peak sensitivity of fish populations exposed to different water types could contribute to our understanding of speciation via the sensory drive and sensory exploitation hypotheses (Endler, 1992; Boughman, 2002). Additionally, some Amazon fish species are morphologically very similar, differing only in some aspects of coloration (e.g., Pires et al., 2019), and knowledge of the level of detail a fish can see may help us understand how subtle 
morphological divergences affect reproductive isolation and species diversification.

\section{Chemoreception}

Chemical signals that transmit information among individuals are often referred to as pheromones. Pheromones can mediate many aspects of intra- and inter-specific communication, such as sociability (Ratchford and Eggleston, 1998), mate recognition and choice (Plenderleith et al., 2005), parental care (Keller-Costa et al., 2015), and predator avoidance (Wisenden, 2000; Griffiths and Richardson, 2006). Some fish innately recognize chemical signals released by predators, and others can learn to associate chemicals with predation risk (Wisenden, 2000; Griffiths and Richardson, 2006). Fish in the Superorder Ostariophysi have evolved an important mechanism to identify dangerous situations, termed "alarm reactions" ("Schreckreaktion") (von Frisch, 1942). Individuals that have been injured (possibly after a predator attack) release chemical alarm signals into the water, inducing behavioral responses in conspecifics that contribute to predator avoidance and increase their probability of survival (Wisenden, 2000; Griffiths and Richardson, 2006; Brown et al., 2012). However, not only Ostariophysian fishes can use chemicals released by injured conspecifics to detect predators; since metabolic products like urea may also trigger similar alarm reactions (Brown et al., 2012).

Pheromones can also mediate aggregation among individuals (Ratchford and Eggleston, 1998), possibly requiring previous contact with such substances (i.e., learning, Keller-Costa et al., 2015). Changes in the chemical environment leading to perturbations of the learning process can reverse sexual preference, and even result in a preference for heterospecifics over conspecifics (Verzijden and Rosenthal, 2011). Chemosensory learning and signaling can be constrained by acidic water conditions, since some fish pheromones can be degraded and reduced to the point that no learning can occur (Brown et al., 2002; Leduc et al., 2007). Additionally, acidic conditions can trigger ion regulatory disturbances (via uptake of $\mathrm{Na}^{+}$and $\mathrm{Ca}^{+}$) (Steinberg et al., 2006), which could affect chemical communication. Knowledge of whether fish in blackwater environments have evolved adaptations in sensory system to cope with the prevailing strongly acidic waters and resulting limitations imposed by the environment is virtually absent.

Sexual pheromones are hydrophobic or amphiphilic molecules (Stacey et al., 2003). As such, these pheromones can either dissolve in water or bind to suspended (DOC) or deposited organic matter (Mesquita et al., 2003). Chemical signals attached to DOC can be altered in ways that are unrecognizable to chemical receptors, precluding behavioral responses (Hubbard et al., 2002; Mesquita et al., 2003). Compared to clear and white water types, blackwater environments have lower $\mathrm{pHs}$ and higher concentrations of DOC and humic and fulvic acids. As such, intra- and inter-specific chemical communication among fishes from highly acidic black waters may be constrained (Figure 3). The influence of high concentrations of humic acids in chemical communication for reproduction has been demonstrated for the swordtail (Xiphophorus birchmanni; Cyprinodontiformes:
Poeciliidae), whose females showed a strong preference for conspecific males' chemical cues, but failed to show any preference for the same chemicals in the presence of high concentrations of dissolved humic acids (Fisher et al., 2006). This illustrates how differences in chemical environments may favor hybridization by weakening or even completely suppressing species recognition mechanisms, which could ultimately affect speciation processes. However, even in the presence of high DOC concentrations, swordtail females expressed their preference for conspecific males when concomitantly exposed to males' visuals cues (Fisher et al., 2006). In this case, when chemical cues were constrained by environmental conditions, individuals used combined sensory modalities to make decisions. Based on these results, it could be expected that organisms living in Amazon blackwater systems would primarily rely on vision to perceive their surroundings, with chemoreception being used as a supporting sensory mechanism.

When visual communication is constrained by environmental characteristics, chemical cues may be more relevant to intra- and inter-specific communication (Dodson et al., 1994). However, as far as we know, the relative importance of chemical communication among species that predominantly inhabit black and white Amazon water types has yet to be investigated. Studies of chemical communication among species that perform seasonal migrations between contrasting water types, such as species of the genus Semaprochilodus (Characiformes: Prochilodontidae) (de Brito Ribeiro and Petrere Junior, 1990), may help us understand how fish adjust their osmotic balance and sensory systems when exposed to diverse environmental conditions. While thoughtprovoking, research on these topics in the Amazon is lacking.

\section{Mechanoreception}

Mechanoreception in fishes includes hearing, touch, and perception of water movement through the lateral line. Fish use mechanoreception to sense the abiotic environment as well as for intra- and inter-specific interactions. Although all of these forms of mechanoreception can be used to detect mechanical vibrations, they differ in how the vibrations are detected and are used for different purposes. Therefore, they will be divided into three subsections and explored individually.

\section{Sound Production and Hearing}

Fish have the ability to produce and detect sounds (Ladich, 2014). However, due to the lack of a specialized vocal organ (such as the larynx in anurans, reptiles, and mammals and the syrinx in birds, Bradbury and Vehrencamp, 2011), fish species that are able to produce sounds do not have large repertoires (Dos Santos et al., 2000; Amorim, 2006). Sounds in fishes are produced in different ways and can be classified in two main mechanisms: sounds produced through (1) the swim bladder; and by (2) stridulatory mechanisms (Kasumyan, 2008). Most sounds produced by fish are created in the swim bladder using drumming (or sonic) muscles that are either attached to the bladder wall or positioned outside (Thorson and Fine, 2002; Ladich, 2014). Contraction of these specialized muscles causes changes in the volume of the swim bladder and in the pressure of the gas inside (Zelick et al., 1999), causing the swim bladder to vibrate 
A

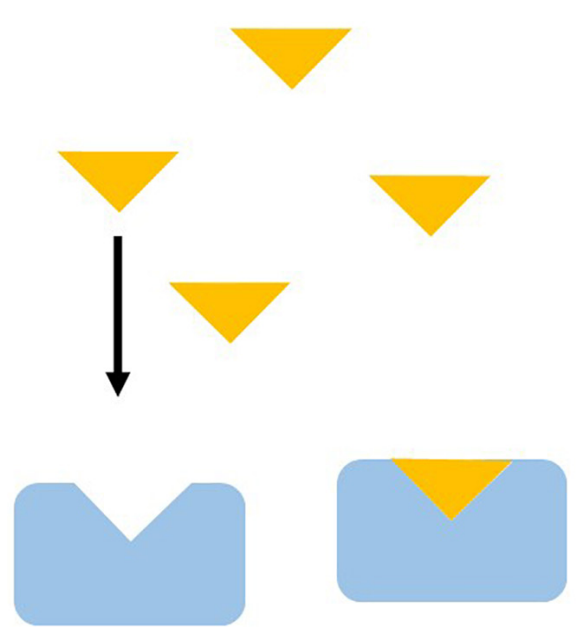

B

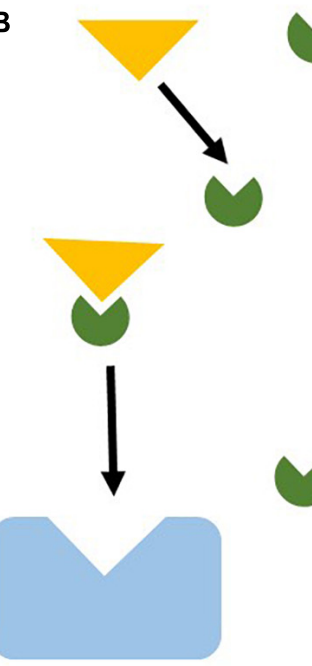

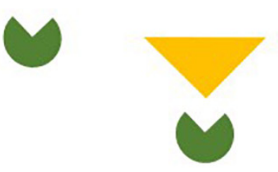
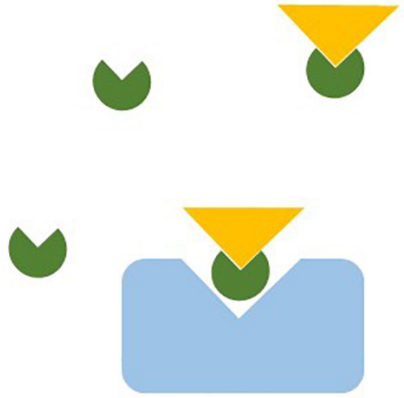

FIGURE 3 | Scheme showing how chemical communication can be impaired by DOC. Blue boxes = chemical receptors, Yellow triangles = pheromones, Green semi-circles = DOC. (A) Pheromones flow through the water column and reach chemical receptors, (B) DOC bind to pheromones, DOC + pheromones complex fail to attach to chemical receptors, not eliciting a behavioral response.

like a loudspeaker. Fish can also produce sounds by vibrating the bladder indirectly, via broad tendons or bones without any direct attachment to the swim bladder wall (Ladich, 2014). Stridulatory sound production occurs mainly in catfish; sounds are generated when a heavily ossified first pectoral-fin ray is pressed against a series of grooves in the shoulder girdle. Some species can even use a sonic muscle to vibrate their entire pectoral girdle (Ladich, 1989, 2014).

Sounds produced by fishes are generally used for intimidation, defense, territorial advertisement, courtship, or mating (Myrberg et al., 1986; Ladich, 1989; Dos Santos et al., 2000). These sounds are detected by the inner ear and by additional peripheral structures that improve hearing (Braun and Grande, 2008; Popper and Fay, 2011; Ladich, 2014). Inner ears are composed of three semicircular canals (utricle, saccule, lagena) and by otoliths (sagittae, lapilli, asterisci) in the semicircular canals. These otoliths are calcareous (calcium carbonate) structures that lie on top of a bed of sensory hair cells (Ladich, 2014). When a sound is produced, it causes a vibration in the water, which moves the otoliths and stimulates the hair cells. Fishes of the Superorder Ostariophysi have an additional hearing structure called the Weberian apparatus that consists of a skeletal modification (a series of small bony elements derived from the first vertebral elements) that connects the swim bladder to the inner ear (Braun and Grande, 2008). This structure acts as an amplifier of the sound waves transmitted through the water to the inner ear (Braun and Grande, 2008).

Deposition of minerals in otoliths are highly dependent on the physical and chemical characteristics of the water, including the presence of different chemical elements (minerals) and pH (Morales-Nin, 2000; Walther and Thorrold, 2006). As such, otoliths formations in fishes living in blackwater systems may be very different from fishes originating in whitewater environments. Black water fish may have otoliths with lower mineral density than those found in white water fish, which may result in lower hearing ability (Oxman et al., 2007; Simpson et al., 2011; Rossi et al., 2016) and affect auditory responses.

Boyle et al. (2015) evaluated morphological structures associated with sound production and sound characteristics in three Amazon doradid catfishes, Acanthodoras cataphractus, Platydoras hancockii, and Agamyxis pectinifrons, revealing the existence of differences in waveform and amplitude modulation. Although distinguishable, the differences in sound parameters between species were not explained by any of the analyzed anatomic features (swim bladder size, muscle anatomy, or muscle length), but instead were suggested to be modulated by means of differences in neural activation of sonic muscles (Boyle et al., 2015). Because sound production may be regulated by neural processes, it arguably plays an important role in intra- and interspecific communication. On the other hand, the Amazon sailfin suckermouth catfish Pterygoplichthys pardalis does not display any behavioral responses to conspecific stridulation sounds, which seem to only be used to deter predators (Slusher, 2018).

Studies evaluating the possible effects of water types on otoliths' mineral deposition and associated auditory responses among Amazon fishes seems to be completely lacking. Notwithstanding, the production of sounds by several fishes just (or mostly) during reproductive activities (courting and mating) indicates its potential importance for correct species pairing during spawning (Amorim et al., 2003). However, the relative importance of audial communication by fish in the different Amazon water types and its possible role on reproductive isolation remains to be verified.

\section{Touch}

Among fishes, tactile reception occurs through free nerve endings, Merkel cells and Rohon-Beard cells, and their associated innervation. Rohon-Beard cells are usually present only during 
the larval phase, while Merkel cells persist throughout the entire life cycle. The main tactile organs of fish are barbels; free rays; filaments of pectoral, dorsal and caudal fins; rostrums; and breeding tubercles. These organs play an important role in reproductive stimulation, exploration, social behavior such as schooling and shoaling, defensive behavior, and foraging (Windsor et al., 2008; Soares and Niemiller, 2013).

Tactile organs are especially well developed among cavefish and other species that inhabit environments with dim or no lighting. To compensate for a lack of the vision, some fishes have enhanced mechanosensory systems. Cavefish species usually have elongated fins, particularly pectoral fins, which are used to touch objects and allow perceiving structures in the environment (Windsor et al., 2008; Soares and Niemiller, 2013). For instance, it has been observed that blind cavefish frequently touch surfaces with their pectoral fins while swimming (Baker and Montgomery, 1999; Windsor et al., 2008) and during rheotaxis (Baker and Montgomery, 1999).

Many Amazonian catfishes have small eye size and elongated fins filaments that likely play an important role for sensing the environment through the mechanosensory system. Such organs may differ depending on water type not only in size, but also in the density of Merkel cells, or even in cell sensitivity. Interestingly, a higher diversity of Amazon catfishes occurs in white waters (Queiroz et al., 2013; Dagosta and de Pinna, 2019) and in the deeper portions of the Amazon's aquatic habitats (e.g., Beltrão et al., 2019) where underwater light is scarce, further stressing the importance of the mechanosensory system in this group. It is therefore unfortunate that the role of touch among species that inhabit black, clear, and white water types has not been investigated.

\section{Mechanoreception by the Lateral Line System}

The lateral line system acts as a "touch-at-a-distance" sense. It provides information about water currents, aiding in prey detection, predator avoidance, hydrodynamic imaging, and courtship communication (Coombs and Montgomery, 1999; Montgomery et al., 2001). The lateral line system is usually externally visible at the body surface and consists of sensory cells called neuromasts, which are found on the skin or underneath the skin surface in fluid-filled canals that are in contact with the water through a series of pores (Bleckmann, 1986, 2006; Coombs, 2001). Neuromasts on the skin are sensitive to low-frequency vibrations, such as water motion and flow velocity, while those found inside the canals are sensitive to higher frequencies, such as pressure and tactile information (Montgomery et al., 1995; Coombs and Montgomery, 1999). Neuromast sensitivity depends on the apical ciliated bundles where the mechanotransducer channels are located (Kazmierczak and Müller, 2012). When water flows over the hair bundles, it causes changes in ion influx, activating signal transduction in the ciliated cells (Sand, 1975; Fettiplace, 2009). Although potassium $\left(\mathrm{K}^{+}\right)$and sodium $\left(\mathrm{Na}^{+}\right)$ ions can flow into the neuromasts, calcium ions $\left(\mathrm{Ca}^{+2}\right)$ play a central role in the activation of transduction (Sand, 1975; Fettiplace, 2009).

The number of neuromasts found in the peripheral lateral line system of a fish can vary from 100 to over 1,000, and are distributed on the head and along the body (Coombs, 2001). Not only the number of neuromasts but their distribution, size, and morphology vary between species (Maruska, 2001). These differences in neuromast structural features could affect their sensitivity, since variations in physical characteristics may confer to the neuromasts the capacity to respond to a specific range of stimuli frequencies (Kroese and Van Netten, 1989).

The number and size of neuromasts varies in response to a range of environmental conditions. In fishes living under very low light conditions, as is the case for the blind cavefish Astyanax mexicanus, the mechanosensory system may be oversized to compensate for lack of vision. Enlarged neuromasts in cavefish can confer a higher sensitivity and a higher range of stimuli than the neuromasts found among surface relatives (Yoshizawa et al., 2014). Conversely, other environmental conditions may impair the development of the lateral line system, also affecting its sensitivity. In zebrafish (Danio rerio) embryos, acidic conditions reduced the number and apical area width of neuromasts along with the size of hair bundles, ultimately reducing neuromast functionality (Lin et al., 2019), but it is still unclear if such impairment lasts throughout an individual's life. Such morphological effects are expected to occur due to the internal $\mathrm{pH}$ balance that may regulate hair cell development and functioning (Lin et al., 2019). Interestingly, exposition to acidic water might affect the $\mathrm{pH}$ of the internal body fluids and the dome of the lateral line hair cells, disrupting $\mathrm{pH}$-sensitive processes. Additionally, aquatic environments with low amount of calcium may also impair the activation of the signal transduction in the ciliated cells (Fettiplace, 2009). Black waters are remarkably acidic, with very small amounts of dissolved salts, especially calcium, compared to white waters (Furch, 1984; Sioli, 1984). Although the pH of clear waters can reach neutral/slightly alkaline values, their calcium concentrations are comparable to those observed among black waters (Table 1). Therefore, the lateral line system of individuals living in black and clear water systems is expected to have fewer neuromasts, with their hair bundles slightly shortened and the apical area of the neuromasts also shortened compared to individuals from white waters (Lin et al., 2019; Figure 4). Such effects of water quality on neuromast characteristics may restrict their functionality. However, it is still unclear if and how divergences in the lateral line system could affect individuals' communication.

Determining the distribution, number and sensitivity of neuromasts in fish populations exposed to different water types could shed light on how divergent Amazon waters may have contributed to shaping fish diversity through differences in lateral line system. The scanning ion-selective electrode technique (SIET) can be used to survey the transport of various ions in biological membranes. Accessing the calcium entry in differently shaped neuromasts in vivo through SIET can show us the sensitivity of the hair cells (Lin et al., 2019). This can be especially important for species that use mechanical communication for accessing mating partners and for triggering spawning events (e.g., Pires et al., 2016) and for species that live in poorly lit environments (such as Amazon white waters), since their visual system may be naturally constrained by low light availability. 

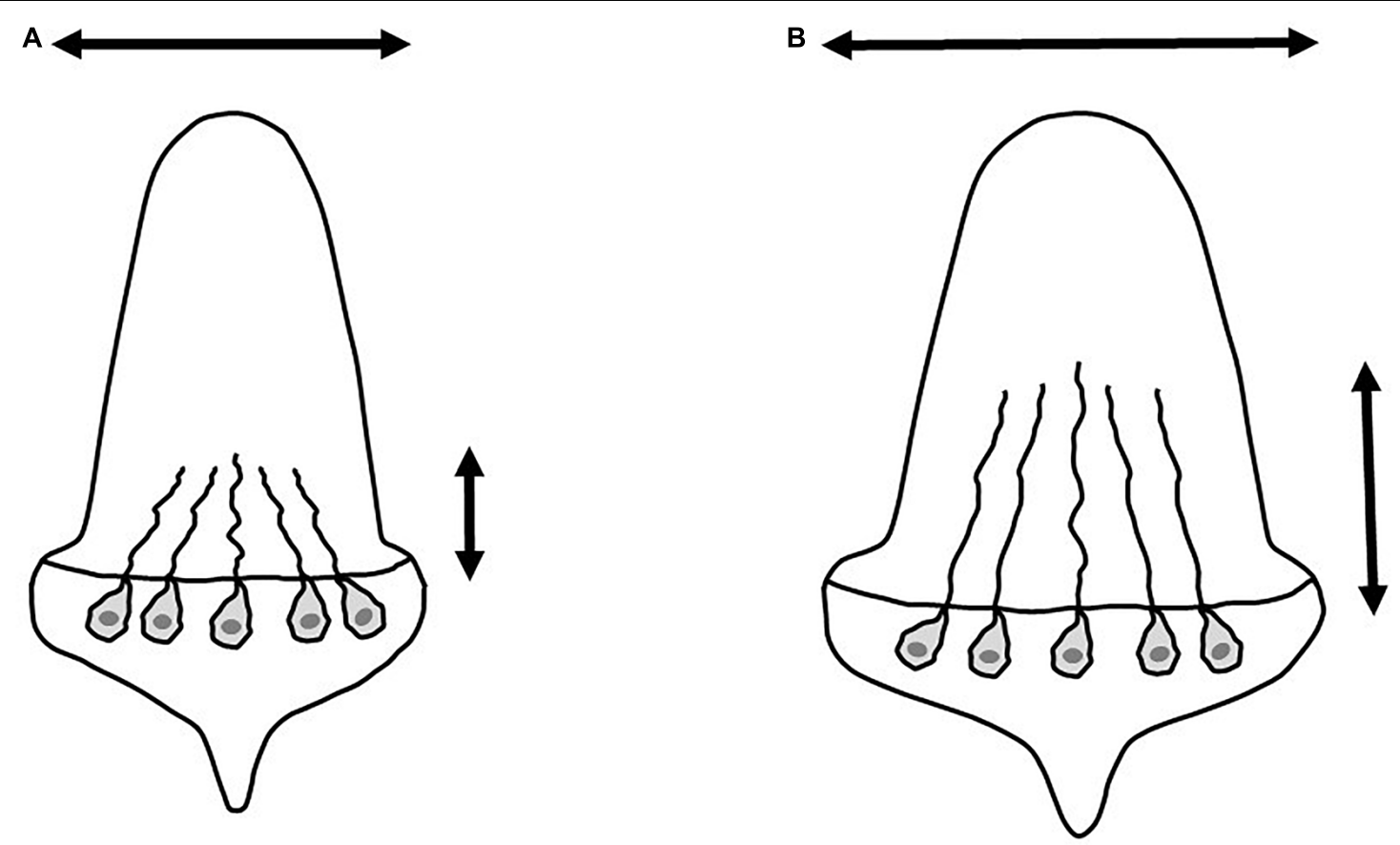

FIGURE 4 | Expected morphological differences in fishes' neuromasts under acidic and neutral/alkaline environments according to Lin et al. (2019). (A) Fishes under acidic environments may show short hair bundles and the apical area of the neuromasts shortened. (B) On the other hand, fishes from neutral/alkaline aquatic environments may show longer hair bundles and larger apical area of the neuromasts. Arrows mark the expected differences in neuromasts shapes.

\section{ELECTRORECEPTION}

Based on morphological similarities, electroreceptors are thought to be derived from mechanoreceptors of the lateral line system (Pitcher, 1986; Crampton, 2019). Electroreceptors can be classified in two groups according to their morphological and physiological characteristics: ampullary or tuberous receptors (Bullock, 1982; Zakon, 1988). Ampullary receptors are sensitive to low electrical frequencies $(0.1-50 \mathrm{~Hz})$ and are used in passive electrolocation and prey detection, while tuberous receptors are sensitive to high-frequency signals $(50-2,000 \mathrm{~Hz})$ and are used for active electrolocation and electrocommunication (Bullock, 1982; Bleckmann, 1986). Ampullary receptors are found on the fish's skin and are filled with mucus, whereas tuberous receptors are covered by the fish's skin and piled up in "packages."

In the Amazon, two closely related orders, Siluriformes and Gymnotiformes, have ampullary receptors. However, only Gymnotiformes are able to both detect and produce electric fields. Such electric fields are generated by electric organs that are mostly derived from muscle tissue (Kramer, 2009; Carlson and Gallant, 2013). These organs are controlled by the brain and are characterized by a greater amplitude, intensity and higher temporal and spatial stability when compared to other electric body signals such as those that control heart rate (Kramer, 2009). Electric organ discharges (EODs) are used for sensing the environment and foraging (Feulner et al., 2009b). EODs are also used for species-specific communication and play an important role in individual recognition and mating activities (Feulner et al., 2009a), which have been suggested to promote speciation among African weakly electric fishes (Mormyridae) (Feulner et al., 2009a,b; Tiedemann et al., 2010). Electric organ discharges can be classified according to the waveform as wave-type or pulsetype. Wave-type electric discharges are continuously produced and generate nearly sinusoidal waveforms. Pulse-type discharges are interrupted by relatively long and sometimes irregular "silent" intervals (Zakon, 1988).

Electric discharges and waveforms can be affected by characteristics of the aquatic environment, such as water temperature and electric conductivity. The EOD rate, frequency (in Hertz) and amplitude (in millivolts) increase with water temperature (Dunlap et al., 2000). Differences in water conductivity can even change the waveform of male individuals to be "female-like" and vice versa (Bratton and Kramer, 1988; Baier, 2008). However, these changes might not interfere in species recognition (Baier, 2008) since some species show a remarkable ability to physiologically acclimate to the changing water conductivity, returning their waveform to close to the original shape within $48 \mathrm{~h}$ (Bell et al., 1976), which may be an adaptation to deal with natural variations in water conditions (Bratton and Kramer, 1988). Although EOD is involved in mate choice (Curtis and Stoddard, 2003; Feulner et al., 2009a), it is not clear how changes in waveform and EOD due to changes in water conductivity affect intrasexual communication. An interesting example on how conductivity can influence sensory information has been provided by MacIver et al. (2001), who showed that the highest prey detection distance occurred in low conductivity and the lowest in high conductivity in Apteronotus albifrons (Gymnotiformes), a weakly electric 
knifefish. Similarly, increased water conductivity may result in a decreased communication range as reported for the African Brienomyrus niger (Mormyriformes) (Squire and Moller, 1982).

Differences in water conductivity of Amazon water types may affect the performance of the electrogenic-electrosensory system of electric fishes. Fishes in white water (high conductivity) may use their electric organs to generate low-voltage, highcurrent electric fields, whereas fishes inhabiting black and clear waters (low conductivity) may generate high-voltage, low-current electric fields, adequate for mediums with high resistance (i.e., the ability of water to resist an electrical current, which is negatively related to the amount of dissolved salts in the water; water with a high concentration of dissolved salts will have a low resistivity, and vice versa) (Kramer, 2009). Ampullary and tuberous electroreceptors are affected by water conductivity in a similar way, and several studies have reported differences in behavioral responses occasioned by changes in electroreception ability (Squire and Moller, 1982; MacIver et al., 2001; Baier, 2008). Fishes that live in environments with high water conductivity possess longer ampullary (sensitive to low frequency) canals, longer receptor cells and more receptor cells than fishes inhabiting low-conductivity waters. Ampullary pores also tend to be larger in species living in high water conductivity (Gauthier et al., 2015). Therefore, electric fishes adapted to white waters may have more numerous and longer receptor cells, as well as larger pores of the ampullary organ than fishes adapted to black and clear water types (Figure 5). Water conductivity may also affect electroreception by tuberous organs (sensitive to high frequency). Tuberous electroreceptor sensitivity is tuned to the same frequency as the electric organ discharge of the species (Hopkins, 1976), and behavioral thresholds to highfrequency stimuli increase with decreasing water conductivity (Knudsen, 1974). Therefore, electric fishes inhabiting whitewater environments may be more sensitive to high-frequency electric signals than those inhabiting black and clear water environments. Although speculative, this represents a simple yet underexplored adaptive hypothesis on the evolution of electroreception in relation to water types.

Divergence in water conductivity may also shape the evolution of electric organ morphology. Fishes adapted to high conductivity waters usually have shorter and thicker caudal filaments containing electrocytes arranged in five or more rows (Hopkins, 2009). On the other hand, fishes adapted to low water conductivity environments possess narrower caudal filaments with only three longitudinal electrocytes arranged in parallel columns (Hopkins, 2009). These morphological adaptations allow fishes to produce electric discharges that are tuned to the limnological characteristics of different aquatic environments.

Investigations regarding how an electric fish from one kind of habitat respond to variations in water conductivity are relatively common (e.g., MacIver et al., 2001). However, only a few studies focused on how fishes inhabiting different water conductivity environments respond to reciprocal changes in water conductivity (e.g., Baier, 2008). Performing this kind of
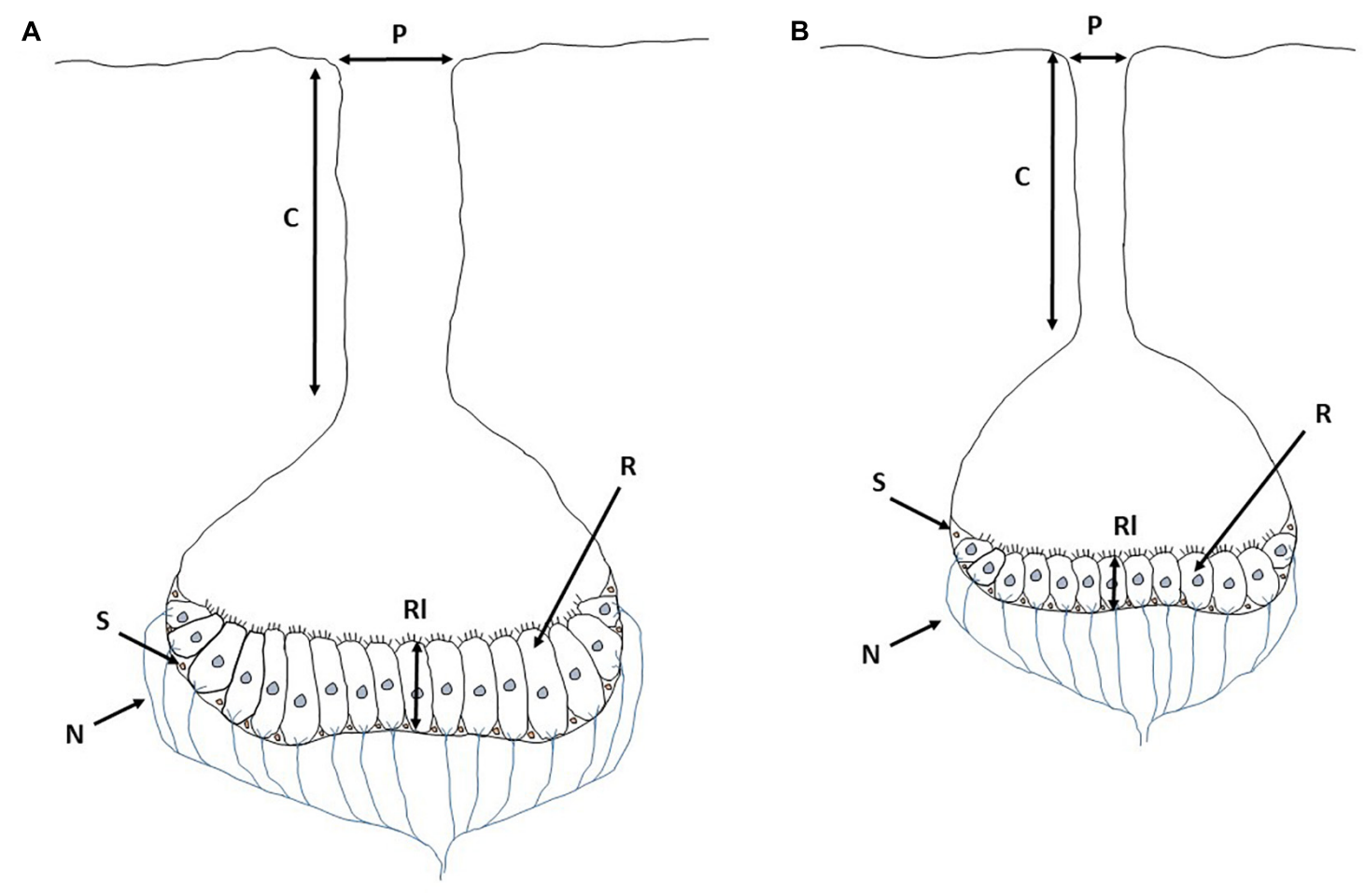

FIGURE 5 | Expected morphological divergence in ampullary organ under (A) high (white water type) and (B) low (Amazon black and clear water types) electric conductivity, according to Gauthier et al. (2015). C, Ampullary canal; P, Pore; R, Receptor cells (cell with gray nucleus in this scheme); RI, Receptors length; S, Supporting cell (cell with light pink nucleus in this scheme); N, Nerve. Draws based on images found in Collin and Whitehead (2004) and Gauthier et al. (2015). 
experiment on fish from Amazon black, clear, and white water types would reveal how characteristics of the electric organ and EOD vary depending on the water conductivity of the habitat of origin and habitat of transplantation, shedding light on how electric conductivity may affect the fish ability to communicate between divergent environmental conditions. Amazon aquatic habitats exhibit seasonal variation in electric conductivity related to river flood cycles and annual rainfall distribution (LoweMcConnell, 1987), however the ability of the electrosensory system to adapt to such natural changes in electric conductivity is largely underexplored.

Adaptations to different water conductivities could affect several aspects of fitness. MacIver et al. (2001) found that fishes in aquatic environments outside the natural range of their species performed poorly in prey detection and predator avoidance. These differences in food intake efficiency could result in additional effects on condition-dependent traits (Greenway et al., 2016). Fish with low body condition due to occupying unfavorable environments may be rejected by potential mating partners. Additionally, differences in waveform could also result in mate rejection, at least in the short term. Therefore, the influence of different Amazon water types on the number, morphology and sensitivity of electroreceptors could result in reproductive barriers and ecological speciation.

\section{CONCLUSION}

It has been suggested that the strikingly different limnological characteristics of the rivers, streams and other water bodies that comprise the Amazon basin are important sources of the divergent selection pressures that may have originated its remarkable fish diversity (Amado et al., 2011; Cooke et al., 2012b,c, 2014; Beheregaray et al., 2015; Pires et al., 2018). Although some authors have suggested the importance of speciation processes mediated by Amazon water types (Cooke et al., 2012b,c; Beheregaray et al., 2015), as far as we know only one study directly evaluated the potential for reproductive isolation among populations exposed to divergent water quality characteristics (Pires et al., 2018). Previous reviews focused on the relative importance of allopatric vs. sympatric speciation but did not explicitly consider mechanisms of speciation, being mostly restricted to the biogeography of speciation. More recently, it has been suggested that differences in lighting environment have shaped the evolution of traits related to visual communication in an Amazonian stream fish species (Pires et al., 2019). However, none of the previous investigations directly evaluated any aspect of the targeted species' sensory systems (Amado et al., 2011; Cooke et al., 2012a,b, 2014; Beheregaray et al., 2015; Pires et al., 2018, 2019).

The sensory drive hypothesis focuses on how sensory/communication systems may adapt to local environments, predicting that divergences in communication systems will arise among populations experiencing contrasting environmental conditions. Such adaptations to communication systems may involve any of the sensory systems: visual, auditory, chemosensory, and even electrosensory. Although some limnologic parameters of the Amazon water bodies vary seasonally (Lowe-McConnell, 1987; Costa et al., 2013), the main characteristics that differentiate the main water types are maintained, arguably sustaining divergent selective pressures that can drive apart sensory systems. Future investigations, as those suggested in the present article, may help us better understand how differences in water types may have contributed to the origin and maintenance of the remarkable fish diversity in the Amazon basin. Although most previously suggested hypotheses consider ecological distinction of the Amazon water types and strongly focus on speciation via allopatry (Albert and Reis, 2011; Albert et al., 2011; Bernardi, 2013), here we suggest some potential mechanisms of divergence mediated by limnologic characteristics that could promote ecological speciation in the aquatic realm of the Amazon basin (Boughman, 2002; Servedio and Boughman, 2017). Different characteristics of the Amazon water types may drive adaptations on fishes' sensory systems that do not necessarily result in conspicuous morphological differences among closely related species. However, these fine-tuned sensory adaptations could have a significant impact on intraspecific communication and eventually result in reproductive isolation among populations or even groups of individuals in the same environment (e.g., Seehausen et al., 2008; Terai and Okada, 2011; Cummings and Endler, 2018). Indeed, several studies have highlighted the occurrence of cryptic species within and among Amazon water types (Cooke et al., 2012a; Pires et al., 2018), but without proposing mechanisms related to water types and the speciation process. In sum, here we hypothesize that the adaptation of fishes' sensory systems driven by contrasting water types have been instrumental in the creation and maintenance of the current fish diversity in the Amazon basin.

\section{DATA AVAILABILITY STATEMENT}

The original contributions presented in the study are included in the article, and further inquiries can be directed to the corresponding author.

\section{AUTHOR CONTRIBUTIONS}

EB and TP contributed to conception and design of the manuscript. EB wrote the first draft of the manuscript. All authors reviewed and approved the submitted version.

\section{FUNDING}

EB was grateful to MEXT (Monbukagakusho \#183957) and JSPS (Core to Core-CETBio/2017-2021). TP was grateful to CAPES, FIXAM/FAPEAM (005/2018) and JST/JICA (SATREPS \#1302260/2015-19). JZ was grateful to $\mathrm{CNPq}$ for the productivity grant (\#313183/2014-7) and JST/JICA (SATREPS \#1302260/2015-19). SK and TI were grateful to JSPS (Core to Core-CETBio/2017-2021) and JST/JICA (SATREPS \#1302260/2015-19). 


\section{ACKNOWLEDGMENTS}

EB was thankful to Egla Gomes Ribeiro for all her support and discussion throughout this manuscript. We are thankful to Fernando C. P. Dagosta, Luciano F. A. Montag, and

\section{REFERENCES}

Albert, J. S., Petry, P., and Reis, R. E. (2011). "Major biogeographic and phylogenetic patterns," in Historical Biogeography of Neotropical Freshwater Fishes, eds J. S. Albert and R. E. Reis (London: University of California Press), 20-57. doi: 10.1525/california/9780520268685.003.0002

Albert, J. S., and Reis, R. (2011). Historical Biogeography of Neotropical Freshwater Fishes. London: University of California Press.

Amado, M. V., Farias, I. P., and Hrbek, T. (2011). A molecular perspective on systematics, taxonomy and classification amazonian discus fishes of the genus Symphysodon. Int. J. Evol. Biol. 2011, 1-16. doi: 10.4061/2011/360654

Amorim, M. C. P. (2006). "Communication in fishes: diversity of sound production in fish," in Communication in Fishes, eds F. Ladich, S. P. Collin, P. Moller, and B. G. Kapoor (Enfield: Science Publishers), 71-105.

Amorim, M. C. P., Fonseca, P. J., and Almada, V. C. (2003). Sound production during courtship and spawning of Oreochromis mossambicus: male-female and male-male interactions. J. Fish Biol. 62, 658-672. doi: 10.1046/j.1095-8649.2003. 00054.x

Atema, J., Fay, R. R., Popper, A. N., and Tavolga, W. N. (1988). Sensory Biology of Aquatic Animals. New York, NY: Springer.

Baier, B. (2008). Effect of conductivity changes on the stability of electric signal waveforms in dwarf stonebashers (Mormyridae; Pollimyrus castelnaui, P. marianne). J. Comp. Physiol. A Neuroethol. Sens. Neural Behav. Physiol. 194, 915-919. doi: 10.1007/s00359-008-0360-0

Baker, C. F., and Montgomery, J. C. (1999). The sensory basis of rheotaxis in the blind Mexican cave fish, Astyanax fasciatus. J. Comp. Physiol. A Neuroethol. Sens. Neural Behav. Physiol. 184, 519-527. doi: 10.1007/s003590050351

Beheregaray, L. B., Cooke, G. M., Chao, N. L., and Landguth, E. L. (2015). Ecological speciation in the tropics: insights from comparative genetic studies in Amazonia. Front. Genet. 5:477. doi: 10.3389/fgene.2014.00477

Bell, C. C., Bradbury, J., and Russell, C. J. J. (1976). The electric organ of a mormyrid as a current and voltage source. J. Comp. Physiol. 110, 65-88. doi: 10.1007/BF00656782

Beltrão, H., Zuanon, J., and Ferreira, E. (2019). Checklist of the ichthyofauna of the Rio Negro basin in the Brazilian Amazon. ZooKeys 881, 53-89. doi: 10.3897/zookeys.881.32055

Bernardi, G. (2013). Speciation in fishes. Mol. Ecol. 22, 5487-5502. doi: 10.1111/ mec. 12494

Bleckmann, H. (1986). "Role of the lateral line in fish behaviour," in The Behaviour of Teleost Fishes, ed. T. J. Pitcher (Boston: Springer), 177-202. doi: 10.1007/9781-4684-8261-4_7

Bleckmann, H. (2006). “The lateral line system of fish,” in Fish Physiology, eds T. J. Hara and B. S. Zielinski (Amsterdam: Elsevier), 411-453. doi: 10.1016/S15465098(06)25010-6

Boughman, J. W. (2002). How sensory drive can promote speciation. Trends Ecol. Evol. 17, 571-577. doi: 10.1016/S0169-5347(02)02595-8

Bowmaker, J. K., and Hunt, D. M. (2006). Evolution of vertebrate visual pigments. Curr. Biol. 16, R484-R489. doi: 10.1016/j.cub.2006.06.016

Boyle, K. S., Riepe, S., Bolen, G., and Parmentier, E. (2015). Variation in swim bladder drumming sounds from three doradid catfish species with similar sonic morphologies. J. Exp. Biol. 218, 2881-2891. doi: 10.1242/jeb.123414

Bradbury, J., and Vehrencamp, S. (2011). Principles of Animal Communication, 2nd Edn. Sunderland: Sinauer Associates.

Bratton, B. O., and Kramer, B. (1988). Intraspecific variability of the pulse-type discharges of the African electric fishes, Pollimyrus isidori and Petrocephalus bovei (Mormyridae, Teleostei), and their dependence on water conductivity. Exp. Biol. 47, 227-238.

Braun, C. B., and Grande, T. (2008). "Evolution of peripheral mechanisms for the enhancement of sound reception," in Fish Bioacoustics, eds J. F. Webb, R. R.
Fabricio B. Baccaro for their comments on the previous version of this manuscript. We are also indebted to Scott H. Jenkins for his thoughtful assistance with the use of English writing. This is contribution \#65 of Projeto Igarapés.

Fay, and A. N. Popper (New York: Springer), 99-144. doi: 10.1007/978-0-38773029-5_4

Brown, G. E., Adrian, J. C., Lewis, M. G., and Tower, J. M. (2002). The effects of reduced $\mathrm{pH}$ on chemical alarm signalling in ostariophysan fishes. Can. J. Fish. Aquat. Sci. 59, 1331-1338. doi: 10.1139/f02-104

Brown, G. E., Jackson, C. D., Malka, P. H., Jacques, É, and Couturier, M. A. (2012). Disturbance cues in freshwater prey fishes: does urea function as an "early warning cue" in juvenile convict cichlids and rainbow trout? Curr. Zool. 58, 250-259. doi: 10.1093/czoolo/58.2.250

Bullock, T. H. (1982). Electroreception. Annu. Rev. Neurosci. 5, 121-170. doi: 10.1146/annurev.ne.05.030182.001005

Carleton, K. L., Parry, J. W. L., Bowmaker, J. K., Hunt, D. M., and Seehausen, O. (2005). Colour vision and speciation in Lake Victoria cichlids of the genus Pundamilia. Mol. Ecol. 14, 4341-4353. doi: 10.1111/j.1365-294X.2005.02735.x

Carlson, B. A., and Gallant, J. R. (2013). From sequence to spike to spark: evo-devoneuroethology of electric communication in mormyrid fishes. J. Neurogenet. 27, 106-129. doi: 10.3109/01677063.2013.799670

Collin, S. P., and Pettigrew, J. D. (1988a). Retinal topography in reef teleosts. Brain Behav. Evol. 31, 269-282. doi: 10.1159/000116594

Collin, S. P., and Pettigrew, J. D. (1988b). Retinal topography in reef teleosts. II. Some species with prominent horizontal streaks and high-density areae. Brain Behav. Evol. 31, 283-295. doi: 10.1159/000116595

Collin, S. P., and Pettigrew, J. D. (1989). Quantitative comparison of the limits on visual spatial resolution set by the ganglion cell layer in twelve species of reef teleosts. Brain Behav. Evol. 34, 184-192. doi: 10.1159/000116504

Collin, S. P., and Whitehead, D. (2004). The functional roles of passive electroreception in non-electric fishes. Anim. Biol. 54, 1-25. doi: 10.1163/ 157075604323010024

Cooke, G. M., Chao, N. L., and Beheregaray, L. B. (2012a). Five cryptic species in the amazonian catfish Centromochlus existimatus identified based on biogeographic predictions and genetic data. PLoS One 7:e48800. doi: 10.1371/ journal.pone.0048800

Cooke, G. M., Chao, N. L., and Beheregaray, L. B. (2012b). Marine incursions, cryptic species and ecological diversification in Amazonia: the biogeographic history of the croaker genus Plagioscion (Sciaenidae). J. Biogeogr. 39, 724-738. doi: 10.1111/j.1365-2699.2011.02635.x

Cooke, G. M., Chao, N. L., and Beheregaray, L. B. (2012c). Natural selection in the water: freshwater invasion and adaptation by water colour in the Amazonian pufferfish. J. Evol. Biol. 25, 1305-1320. doi: 10.1111/j.1420-9101.2012.02514.x

Cooke, G. M., Landguth, E. L., and Beheregaray, L. B. (2014). Riverscape genetics identifies replicated ecological divergence across an Amazonian ecotone. Evolution 68, 1947-1960. doi: 10.1111/evo.12410

Coombs, S. (2001). Smart skins: information processing by lateral line flow sensors. Auton. Robots 11, 255-261. doi: 10.1023/A:1012491007495

Coombs, S., and Montgomery, J. C. (1999). “The enigmatic lateral line system,” in Comparative Hearing: Fish and Amphibians, eds R. R. Fay and A. N. Popper (New York: Springer), 319-362. doi: 10.1007/978-1-4612-0533-3_8

Costa, M. P. F., Novo, E. M. L. M., and Telmer, K. H. (2013). Spatial and temporal variability of light attenuation in large rivers of the Amazon. Hydrobiologia 702, 171-190. doi: 10.1007/s10750-012-1319-2

Crampton, W. G. R. (2019). Electroreception, electrogenesis and electric signal evolution. J. Fish Biol. 95, 92-134. doi: 10.1111/jfb.13922

Cronin, T. W., Johnsen, S., Marshall, J., and Warrant, E. (2014). Visual Ecology. New Jersey: Princeton University Press.

Cummings, M. E., and Endler, J. A. (2018). 25 Years of sensory drive: the evidence and its watery bias. Curr. Zool. 64, 471-484. doi: 10.1093/cz/zoy043

Curtis, C. C., and Stoddard, P. K. (2003). Mate preference in female electric fish, Brachyhypopomus pinnicaudatus. Anim. Behav. 66, 329-336. doi: 10.1006/anbe. 2003.2216 
Dagosta, F. C. P., and de Pinna, M. C. C. (2018). A history of the biogeography of Amazonian fishes. Neotrop. Ichthyol. 16, 1-19. doi: 10.1590/1982-022420180023

Dagosta, F. C. P., and de Pinna, M. C. C. (2019). The fishes of the Amazon: distribution and biogeographical patterns, with a comprehensive list of species. Bull. Am. Museum Nat. Hist. 2019:1. doi: 10.1206/0003-0090.431.1.1

de Brito Ribeiro, M. C. L., and Petrere Junior, M. (1990). Fisheries ecololgy and management of the Jaraqui (Semaprochilodus taeniurus, S. insignis) in central Amazonia. Regul. Rivers Res. Manag. 5, 195-215. doi: 10.1002/rrr.3450050302

Dijkstra, P. D., Seehausen, O., and Groothuis, T. G. G. (2005). Direct male-male competition can facilitate invasion of new colour types in Lake Victoria cichlids. Behav. Ecol. Sociobiol. 58, 136-143. doi: 10.1007/s00265-005-0919-5

Dodson, S. I., Crowl, T. A., Peckarsky, B. L., Kats, L. B., Covich, A. P., and Culp, J. M. (1994). Non-visual communication in freshwater benthos: an overview. J. N. Am. Benthol. Soc. 13, 268-282. doi: 10.2307/1467245

Dos Santos, M. E., Modesto, T., Matos, R. J., Grober, M. S., Oliveira, R. F., and Canário, A. (2000). Sound production by the lusitanian toad fish, Halobatrachus didactylus. Bioacoustics 10, 309-321. doi: 10.1080/09524622.2000.9753440

Dunlap, K. D., Smith, G. T., and Yekta, A. (2000). Temperature dependence of electrocommunication signals and their underlying neural rhythms in the weakly electric fish, Apteronotus leptorhynchus. Brain Behav. Evol. 55, 152-162. doi: 10.1159/000006649

Endler, J. A. (1991). Variation in the appearance of guppy color patterns to guppies and their predators under different visual conditions. Vis. Res. 31, 587-608. doi: 10.1016/0042-6989(91)90109-I

Endler, J. A. (1992). Signals, signal conditions, and the direction of evolution. Am. Nat. 139, S125-S153. doi: 10.1086/285308

Escobar-Camacho, D., Ramos, E., Martins, C., and Carleton, K. L. (2017). The opsin genes of Amazonian cichlids. Mol. Ecol. 26, 1343-1356. doi: 10.1111/mec. 13957

Fabrin, T. M. C., Prioli, S. M. A. P., and Prioli, A. J. (2017). Longwavelength sensitive opsin (LWS) gene variability in Neotropical cichlids (Teleostei: Cichlidae). An. Acad. Bras. Cienc. 89, 213-222. doi: 10.1590/00013765201720150692

Fettiplace, R. (2009). Defining features of the hair cell mechanoelectrical transducer channel. Pflügers Arch. Eur. J. Physiol. 458, 1115-1123. doi: 10.1007/s00424009-0683-x

Feulner, P. G. D., Plath, M., Engelmann, J., Kirschbaum, F., and Tiedemann, R. (2009a). Electrifying love: electric fish use species-specific discharge for mate recognition. Biol. Lett. 5, 225-228. doi: 10.1098/rsbl.2008.0566

Feulner, P. G. D., Plath, M., Engelmann, J., Kirschbaum, F., and Tiedemann, R. (2009b). Magic trait electric organ discharge (EOD): dual function of electric signals promotes speciation in African weakly electric fish. Commun. Integr. Biol. 2, 329-331. doi: 10.4161/cib.2.4.8386

Fisher, H. S., Wong, B. B. M., and Rosenthal, G. G. (2006). Alteration of the chemical environment disrupts communication in a freshwater fish. Proc. $R$. Soc. B Biol. Sci. 273, 1187-1193. doi: 10.1098/rspb.2005.3406

Fricke, R., Eschmeyer, W., and Van Der Laan, R. (2020). Eschmeyer's Catalog of Fishes: Genera, Species, References. Available online at: http://researcharchive. calacademy.org/research/ichthyology/catalog/fishcatmain.asp (accessed October 29, 2020).

Fuller, R. C. (2002). Lighting environment predicts the relative abundance of male colour morphs in bluefin killifish (Lucania goodei) populations. Proc. R. Soc. B Biol. Sci. 269, 1457-1465. doi: 10.1098/rspb.2002.2042

Furch, K. (1984). "Water chemistry of the Amazon basin: the distribution of chemical elements among freshwaters," in The Amazon. Monographiae Biologicae, ed. H. Sioli (Dordrecht: Springer), 167-199. doi: 10.1007/978-94009-6542-3_6

Gauthier, A. R. G., Whitehead, D. L., Bennett, M. B., and Tibbetts, I. R. (2015). Morphology of the teleost ampullary organs in marine salmontail catfish Neoarius graeffei (Pisces: Ariidae) with comparative analysis to freshwater and estuarine conspecifics. J. Morphol. 276, 1047-1054. doi: 10.1002/jmor.20396

Géry, J. (1984). “The fishes of Amazonia," in The Amazon, ed. H. Sioli (Dordrecht: Springer), 353-370. doi: 10.1007/978-94-009-6542-3_14

Goulding, M., Cañas, C., Barthem, R., Forsberg, B., and Ortega, H. (2003). Amazon headwaters: Rivers, wildlife, and conservation in Southeastern Peru. Lima: Asociaciòn para la conservaciòn de la cuenca Amazònica (ACCA).
Greenway, R., Drexler, S., Arias-Rodriguez, L., and Tobler, M. (2016). Adaptive, but not condition-dependent, body shape differences contribute to assortative mating preferences during ecological speciation. Evolution 70, 2809-2822. doi: 10.1111/evo.13087

Griffiths, C. L., and Richardson, C. A. (2006). Chemically induced predator avoidance behaviour in the burrowing bivalve Macoma balthica. J. Exp. Mar. Bio. Ecol. 331, 91-98. doi: 10.1016/j.jembe.2005.10.002

Hopkins, C. D. (1976). Stimulus filtering and electroreception: tuberous electroreceptors in three species of Gymnotoid fish. J. Comp. Physiol. A 111, 171-207. doi: 10.1007/BF00605531

Hopkins, C. D. (2009). "Electrical perception and communication," in Encyclopedia of Neuroscience, ed. L. Squire (Amsterdam: Elsevier), 813-831. doi: 10.1016/ b978-008045046-9.01827-1

Hubbard, P. C., Barata, E. N., and Canario, A. V. M. (2002). Possible disruption of pheromonal communication by humic acid in the goldfish, Carassius auratus. Aquat. Toxicol. 60, 169-183. doi: 10.1016/S0166-445X(02)00002-4

Kasumyan, A. O. (2008). Sounds and sound production in fishes. J. Ichthyol. 48, 981-1030. doi: 10.1134/S0032945208110039

Kazmierczak, P., and Müller, U. (2012). Sensing sound: molecules that orchestrate mechanotransduction by hair cells. Trends Neurosci. 35, 220-229. doi: 10.1016/ j.tins.2011.10.007

Keller-Costa, T., Canário, A. V. M., and Hubbard, P. C. (2015). Chemical communication in cichlids: a mini-review. Gen. Comp. Endocrinol. 221, 64-74. doi: 10.1016/j.ygcen.2015.01.001

Knudsen, E. I. (1974). Behavioral thresholds to electric signals in high frequency electric fish. J. Comp. Physiol. 91, 333-353. doi: 10.1007/BF00694465

Kramer, B. (2009). "Electric organ discharge," in Encyclopedia of Neuroscience, eds M. D. Binder, N. Hirokawa, and U. Windhorst (Berlin: Springer), 1050-1056. doi: 10.1007/978-3-540-29678-2_2917

Kroese, A. B. A., and Van Netten, S. M. (1989). "Sensory transduction in lateral line hair cells," in The Mechanosensory Lateral Line, eds S. Coombs, P. Görner, and H. Münz (New York: Springer), 265-284. doi: 10.1007/978-1-4612-3560-6_13

Küchler, I. L., Miekeley, N., and Forsberg, B. R. (2000). A contribution to the chemical characterization of rivers in the Rio Negro basin. Brazil. J. Braz. Chem. Soc. 11, 286-292. doi: 10.1590/S0103-50532000000300015

Kullander, S. O. (1986). Cichlid Fishes of the Amazon River Drainage of Peru. Sweden: Stockolm.

Ladich, F. (1989). Sound production by the river bullhead, Cottus gobio L. (Cottidae, Teleostei). J. Fish Biol. 35, 531-538. doi: 10.1111/j.1095-8649.1989. tb03004.x

Ladich, F. (2014). Fish bioacoustics. Curr. Opin. Neurobiol. 28, 121-127. doi: 10. 1016/j.conb.2014.06.013

Leduc, A. O. H. C., Roh, E., Breau, C., and Brown, G. E. (2007). Effects of ambient acidity on chemosensory learning: an example of an environmental constraint on acquired predator recognition in wild juvenile Atlantic salmon (Salmo salar). Ecol. Freshw. Fish 16, 385-394. doi: 10.1111/j.1600-0633.2007.00233.x

Leenheer, J. A. (1980). Origin and nature of humic substances in the waters in the Amazon river basin. Acta Amaz. 10, 513-526. doi: 10.1590/180943921980103513

Lin, L. Y., Hung, G. Y., Yeh, Y. H., Chen, S. W., and Horng, J. L. (2019). Acidified water impairs the lateral line system of zebrafish embryos. Aquat. Toxicol. 217:105351. doi: 10.1016/j.aquatox.2019.105351

Lowe-McConnell, R. H. (1987). Ecological Studies in Tropical Fish Communities. Cambridge, MA: Cambridge University Press.

MacIver, M. A., Sharabash, N. M., and Nelson, M. E. (2001). Prey-capture behavior in gymnotid electric fish: motion analysis and effects of water conductivity. J. Exp. Biol. 204, 543-557.

Maruska, K. P. (2001). Morphology of the mechanosensory lateral line system in elasmobranch fishes: ecological and behavioral considerations. Environ. Biol. Fishes 60, 47-75. doi: 10.1023/A:1007647924559

Mendonça, F. P., Magnusson, W. E., and Zuanon, J. (2005). Relationships between habitat characteristics and fish assemblages in small streams of central Amazonia. Copeia 2005, 751-764. doi: 10.1643/0045-8511(2005)005[0751: rbhcaf $] 2.0 . \mathrm{co} ; 2$

Mesquita, R. M. R. S., Canário, A. V. M., and Melo, E. (2003). Partition of fish pheromones between water and aggregates of humic acids. Consequences for sexual signaling. Environ. Sci. Technol. 37, 742-746. doi: 10.1021/es025987e 
Montgomery, J., Coombs, S., and Halstead, M. (1995). Biology of the mechanosensory lateral line in fishes. Rev. Fish Biol. Fish. 5, 399-416. doi: 10.1007/BF01103813

Montgomery, J. C., Coombs, S., and Baker, C. F. (2001). "The mechanosensory lateral line system of the hypogean form of Astyanax fasciatus," in The Biology of Hypogean Fishes. Developments in Environmental Biology of Fishes, ed. A. Romero (Dordrecht: Springer), 87-96. doi: 10.1007/978-94-015-9795-1_5

Morales-Nin, B. (2000). Review of the growth regulation processes of otolith daily increment formation. Fish. Res. 46, 53-67. doi: 10.1016/S0165-7836(00)00 133-8

Muntz, W. R. A. (1978). A penetração de luz nas água de rios amazônicos. Acta Amaz. 8, 613-619. doi: 10.1590/1809-43921978084613

Myrberg, A. A., Mohler, M., and Catala, J. D. (1986). Sound production by males of a coral reef fish (Pomacentrus partitus): its significance to females. Anim. Behav. 34, 913-923. doi: 10.1016/S0003-3472(86)80077-X

Nakamura, E. L. (1968). Visual acuity of two tunas, Katsuwonus pelamis and Euthynnus affinis. Copeia 1968, 41-49. doi: 10.2307/1441548

Nelson, D. L., and Cox, M. M. (2014). Princípios de Bioquímica de Lehninger, 6th Edn. Porto Alegre: Artmed.

Nosil, P. (2012). Ecological Speciation. New York, NY: Oxford University Press.

Oxman, D. S., Barnett-Johnson, R., Smith, M. E., Coffin, A., Miller, D. L. Josephson, R., et al. (2007). The effect of vaterite deposition on sound reception, otolith morphology, and inner ear sensory epithelia in hatchery-reared Chinook salmon (Oncorhynchus tshawytscha). Can. J. Fish. Aquat. Sci. 64, 1469-1478. doi: 10.1139/f07-106

Parker, A. N., Fritsches, K. A., Newport, C., Wallis, G., and Siebeck, U. E. (2017). Comparison of functional and anatomical estimations of visual acuity in two species of coral reef fish. J. Exp. Biol. 220, 2387-2396. doi: 10.1242/jeb.149575

Partridge, J. C., Archer, S. N., and Lythgoe, J. N. (1988). Visual pigments in the individual rods of deep-sea fishes. J. Comp. Physiol. A 162, 543-550. doi: 10. 1007/BF00612519

Pinto, K. S., Pires, T. H. S., Stefanelli-Silva, G., Barros, B. S., Borghezan, E. A., and Zuanon, J. (2020). Does soil color affect fish evolution? Differences in color change rate between lineages of the sailfin tetra. Neotrop. Ichthyol. 18:e190093. doi: 10.1590/1982-0224-2019-0093

Pires, T. H. S., Borghezan, E. A., Cunha, S. L. R., Leitão, R. P., Pinto, K. S., and Zuanon, J. (2019). Sensory drive in colourful waters: morphological variation suggests combined natural and sexual selection in an Amazonian fish. Biol. J. Linn. Soc. 127, 351-360. doi: 10.1093/biolinnean/blz054

Pires, T. H. S., Borghezan, E. A., Machado, V. N., Powell, D. L., Röpke, C. P., Oliveira, C., et al. (2018). Testing Wallace's intuition: water type, reproductive isolation and divergence in an Amazonian fish. J. Evol. Biol. 31, 882-892. doi: $10.1111 /$ jeb. 13272

Pires, T. H. S., Farago, T. B., Campos, D. F., Cardoso, G. M., and Zuanon, J. (2016). Traits of a lineage with extraordinary geographical range: ecology, behavior and life-history of the sailfin tetra Crenuchus spilurus. Environ. Biol. Fishes 99, 925-937. doi: 10.1007/s10641-016-0534-5

Pitcher, T. J. (1986). The Behaviour of Teleost Fishes. Boston: Springer.

Plenderleith, M., Van Oosterhout, C., Robinson, R. L., and Turner, G. F. (2005). Female preference for conspecific males based on olfactory cues in a Lake Malawi cichlid fish. Biol. Lett. 1, 411-414. doi: 10.1098/rsbl.2005.0355

Popper, A. N., and Fay, R. R. (2011). Rethinking sound detection by fishes. Hear. Res. 273, 25-36. doi: 10.1016/j.heares.2009.12.023

Queiroz, L. J., Ohara, W., Zuanon, J., Pires, T. H. S., Torrente-Vilara, G., and Dória, C. R. C. (2013). Peixes do Rio Madeira. São Paulo: Dialeto.

Quesada, C. A., Lloyd, J., Anderson, L. O., Fyllas, N. M., Schwarz, M., and Czimczik, C. I. (2011). Soils of Amazonia with particular reference to the RAINFOR sites. Biogeosciences 8, 1415-1440. doi: 10.5194/bg-8-1415-2011

Ratchford, S., and Eggleston, D. (1998). Size- and scale-dependent chemical attraction contribute to an ontogenetic shift in sociality. Anim. Behav. 56, 1027-1034. doi: 10.1006/anbe.1998.0869

Reis, R. E. (2013). Conserving the freshwater fishes of South America. Int. Zoo Yearb. 47, 65-70. doi: 10.1111/izy.12000

Ríos-Villamizar, E. A., Piedade, M. T. F., Da Costa, J. G., Adeney, J. M., and Junk, W. J. (2013). Chemistry of different Amazonian water types for river classification: a preliminary review. WIT Trans. Ecol. Environ. 178, 17-28.

Roberts, T. R. (1972). Ecology of fishes in the Amazon and Congo basins. Bull. Museum Comp. Zool. 143, 117-147.
Rossi, T., Nagelkerken, I., Pistevos, J. C. A., and Connell, S. D. (2016). Lost at sea: ocean acidification undermines larval fish orientation via altered hearing and marine soundscape modification. Biol. Lett. 12:20150937. doi: 10.1098/rsbl. 2015.0937

Sand, O. (1975). Effects of different ionic environments on the mechano-sensitivity of lateral line organs in the mudpuppy. J. Comp. Physiol. A 102, 27-42. doi: 10.1007/BF00657483

Seehausen, O., Terai, Y., Magalhaes, I. S., Carleton, K. L., Mrosso, H. D. J., Miyagi, R., et al. (2008). Speciation through sensory drive in cichlid fish. Nature 455, 620-626. doi: 10.1038/nature07285

Servedio, M. R., and Boughman, J. W. (2017). The role of sexual selection in local adaptation and speciation. Annu. Rev. Ecol. Evol. Syst. 48, 85-109. doi: 10.1146/annurev-ecolsys-110316-022905

Simpson, S. D., Munday, P. L., Wittenrich, M. L., Manassa, R., Dixson, D. L., Gagliano, M., et al. (2011). Ocean acidification erodes crucial auditory behaviour in a marine fish. Biol. Lett. 7, 917-920. doi: 10.1098/rsbl.2011. 0293

Sioli, H. (1984). "Introduction: history of the discovery of the Amazon and of research of Amazonian waters and landscapes," in The Amazon. Monographiae Biologicae, ed. H. Sioli (Dordrecht: Springer), 1-13. doi: 10.1007/978-94-0096542-3_1

Slusher, M. (2018). Morphological Correlates and Behavioral Functions of Sound Production in Loricariid Catfish, with a Focus on Pterygoplichthys pardalis (Castelnau, 1855). Portland, OR: Portland State University.

Soares, D., and Niemiller, M. L. (2013). Sensory adaptations of fishes to subterranean environments. Bioscience 63, 274-283. doi: 10.1525/bio.2013. 63.4 .7

Squire, A., and Moller, P. (1982). Effects of water conductivity on electrocommunication in the weak-electric fish Brienomyrus niger (Mormyriformes). Anim. Behav. 30, 375-382. doi: 10.1016/S0003-3472(82) 80048-1

Stacey, N., Chojnacki, A., Narayanan, A., Cole, T., and Murphy, C. (2003). Hormonally derived sex pheromones in fish: exogenous cues and signals from gonad to brain. Can. J. Physiol. Pharmacol. 81, 329-341. doi: 10.1139/y0 3-024

Steinberg, C. E. W., Kamara, S., Prokhotskaya, V. Y., Manusadžianas, L., Karasyova, T. A., Timofeyev, M. A., et al. (2006). Dissolved humic substances - Ecological driving forces from the individual to the ecosystem level? Freshw. Biol. 51, 1189-1210. doi: 10.1111/j.1365-2427.2006.01571.x

Terai, Y., and Okada, N. (2011). "Speciation of cichlid fishes by sensory drive," in The Chimpanzees of Bossou and Nimba, eds M. Inoue-Murayama, S. Kawamura, and A. Weiss (Tokyo: Springer), 311-328. doi: 10.1007/978-4-431-5389 2-9_15

Terai, Y., Seehausen, O., Sasaki, T., Takahashi, K., Mizoiri, S., Sugawara, T., et al. (2006). Divergent selection on opsins drives incipient speciation in Lake Victoria cichlids. PLoS Biol. 4:e433. doi: 10.1371/journal.pbio.004 0433

Thorson, R. F., and Fine, M. L. (2002). Acoustic competition in the gulf toadfish Opsanus beta: acoustic tagging. J. Acoust. Soc. Am. 111:2302. doi: 10.1121/1. 1466865

Tiedemann, R., Feulner, P. G. D., and Kirschbaum, F. (2010). "Electric organ discharge divergence promotes ecological speciation in sympatrically occurring african weakly electric fish (Campylomormyrus)," in Evolution in Action, ed. M. Glaubrecht (Berlin: Springer), 307-321. doi: 10.1007/978-3-642-1242 5-9_15

Van Nynatten, A., Bloom, D., Chang, B. S. W., Lovejoy, N. R., and Lovejoy, N. R. (2015). Out of the blue: adaptive visual pigment evolution accompanies Amazon invasion. Biol. Lett. 11:20150349. doi: 10.1098/rsbl.2015. 0349

Verzijden, M. N., and Rosenthal, G. G. (2011). Effects of sensory modality on learned mate preferences in female swordtails. Anim. Behav. 82, 557-562. doi: 10.1016/j.anbehav.2011.06.010

von Frisch, K. (1942). Über einen schreckstoff der fischhaut und seine biologische bedeutung. Z. Vgl. Physiol. 29, 46-145. doi: 10.1007/BF0030 4445

Wallace, A. R. (1853). A Narrative of Travels on the Amazon and Rio Negro: With an Account of the Native Tribes, and Observations on the Climate, Geology, and Natural History of the Amazon Valley. London: Reeve and Co. 
Walther, B. D., and Thorrold, S. R. (2006). Water, not food, contributes the majority of strontium and barium deposited in the otoliths of a marine fish. Mar. Ecol. Prog. Ser. 311, 125-130. doi: 10.3354/meps311 125

Warrant, E. (2004). Vision in the dimmest habitats on Earth. J. Comp. Physiol. A 190, 765-789. doi: 10.1007/s00359-004-0546-Z

Windsor, S. P., Tan, D., and Montgomery, J. C. (2008). Swimming kinematics and hydrodynamic imaging in the blind Mexican cave fish (Astyanax fasciatus). J. Exp. Biol. 211, 2950-2959. doi: 10.1242/jeb.020453

Wisenden, B. D. (2000). Olfactory assessment of predation risk in the aquatic environment. Philos. Trans. R. Soc. B Biol. Sci. 355, 1205-1208. doi: 10.1098/ rstb.2000.0668

Yoshizawa, M., Jeffery, W. R., van Netten, S. M., and McHenry, M. J. (2014). The sensitivity of lateral line receptors and their role in the behavior of Mexican blind cavefish (Astyanax mexicanus). J. Exp. Biol. 217, 886-895. doi: 10.1242/ jeb.094599

Zakon, H. H. (1988). “The electroreceptors: diversity in structure and function," in Sensory Biology of Aquatic Animals, eds J. Atema, R. R. Fay, A. N. Popper, and
W. N. Tavolga (New York: Springer), 813-850. doi: 10.1007/978-1-4612-371 4-3_32

Zelick, R., Mann, D. A., and Popper, A. N. (1999). “Acoustic communication in fishes and frogs," in Comparative Hearing: Fish and Amphibians, eds R. R. Fay and A. N. Popper (New York: Springer), 363-411. doi: 10.1007/978-1-46120533-3_9

Conflict of Interest: The authors declare that the research was conducted in the absence of any commercial or financial relationships that could be construed as a potential conflict of interest.

Copyright (c) 2021 Borghezan, Pires, Ikeda, Zuanon and Kohshima. This is an openaccess article distributed under the terms of the Creative Commons Attribution License (CC BY). The use, distribution or reproduction in other forums is permitted, provided the original author(s) and the copyright owner(s) are credited and that the original publication in this journal is cited, in accordance with accepted academic practice. No use, distribution or reproduction is permitted which does not comply with these terms. 